\title{
Tinjauan Yuridis terhadap Tindak Pidana Pembunuhan Berencana Menggunakan Besi Padat di Medan Tinjauan Kasus Nomor 2305/Pid.B/2017/Pn.Mdn
}

\section{Juridical Review of Criminal Offenses Planning to Use Solid Iron in Medan Case Review Number 2305/Pid.B/2017/ Pn.Mdn}

\author{
Vera Eva Bonita Simbolon, Meri Simarmata \& Rahmayanti* \\ Program Studi Ilmu Hukum, Fakultas Hukum, Universitas Prima Indonesia, Indonesia
}

*Coresponding Email: rahmayanti888@yahoo.com

\begin{abstract}
Abstrak
Penelitian ini bertujuan, untuk mengetahui faktor - faktor apa saja yang menyebabkan terjadinya pembunuhan berencana dan pertanggungjawaban pelaku tindak pidana pembunuhan berencana berdasarkan KUHP. Metode penelitian digunakan secara yuridis normatif. Pengumpulan data diperoleh dari studi kepustakaan dan putusan pengadilan. Hasil penelitian dan pembahasan ini menunjukkan bahwa faktor yang menyebabkan seseorang melakukan tindak pidana pembunuhan berencana menggunakan besi padat bersumber dari faktor eksternal yaitu faktor agama, keluarga, pendidikan dan faktor internal yaitu faktor ekonomi, lingkungan, obat-obatan terlarang dan media sosial. Upaya penanggulangan yang dilakukan terhadap kejahatan pembunuhan berencana menggunakan besi padat dilakukan dengan sarana non-penal dan penal secara preventif maupun represif.
\end{abstract}

Kata Kunci: Tindak pidana; Pembunuhan Berencana; dan Besi Padat.

\begin{abstract}
This study aims to find out what factors cause the premeditated murder and the accountability of the perpetrators of the crime of premeditated murder under the Criminal Code. The research method used is normative juridical. Data collection is obtained from library studies and court decisions. The results of this study and discussion show that the factors that cause a person to commit a crime of premeditated murder using solid iron come from external factors, namely religion, family, education and internal factors, namely economic, environmental, drug and social media factors. Prevention measures taken against the crime of premeditated murder using solid iron are carried out by means of non-reasoning and preventive and repressive reasoning.
\end{abstract}

Keywords: Criminal act; Premeditated Murder; and Solid Iron.

How to Cite: Simbolon, V.E.B. Simarmata, M. \& Rahmayanti. (2019). Tinjauan Yuridis terhadap Tindak Pidana Pembunuhan Berencana Menggunakan Besi Padat di Medan Tinjauan Kasus Nomor 2305/Pid.B/2017/Pn.Mdn. Jurnal Mercatoria. 12 (1): 54-67.

Dikirim: 17 Maret 2019; Diterima: 19 Juni 2019; Dipublish: 25 Juni 2019 


\section{PENDAHULUAN}

Negara Indonesia adalah Negara berdasarkan atas hukum, sehingga setiap kegiatan manusia atau masyarakat yang merupakan aktivitas hidupnya harus berdasarkan pada peraturan yang ada dan norma-norma yang berlaku dalam masyarakat. Hukum tidak lepas dari kehidupan manusia karena hukum merupakan aturan untuk mengatur tingkah laku manusia dalam kehidupannya karena tanpa adanya hukum kita tidak dapat membayangkan akan seperti apa negara ini.

Dalam negara hukum, hukum merupakan tiang utama dalam menggerakkan sendi-sendi kehidupan masyarakat, berbangsa dan bernegara. Salah satu ciri utama dari suatu negara hukum, terletak pada kecenderungannya untuk menilai tindakan-tindakan yang dilakukan oleh masyarakat atas dasar peraturan hukum. Artinya bahwa sebuah negara dalam konsep negara hukum selalu mengatur pada setiap tindakan dan tingkah laku masyarakatnya berdasarkan atas dasar undang-undang yang berlaku untuk menciptakan, memelihara, dan mempertahankan kedamaian pergaulan hidup, agar sesuai dengan apa yang diamanatkan dalam Pancasila dan UUD 1945 yaitu setiap warga negara berhak atas rasa aman dan bebas dari segala bentuk kejahatan (Asshiddiqie, 2006).

Salah satu masalah yang sering muncul dimasyarakat adalah tindak pidana pembunuhan, tindak pidana pembunuhan adalah salah satu bentuk kejahatan dalam jiwa seseorang dimana perbuatan tersebut sangat bertentangan dengan norma-norma dan hukum yang ada dalam masyarakat yaitu norma agama dan hukum adat istiadat, sekaligus bertentangan dengan norma ketentuan hukum pidana dan melanggar hak asasi manusia yaitu hak untuk hidup.

Sebagaimana menurut pendapat $\mathrm{R}$. Soesilo dalam bukunya mengatakan bahwa "Pembunuhan berencana merupakan suatu pembunuhan yang dilakukan dengan direncanakan terlebih dahulu dalam artian bahwa antara timbulnya maksud untuk membunuh dengan pelaksanaanya itu masih ada tempo bagi si pelaku untuk dengan tenang memikirkannya, misalnya dengan cara bagaimanakah pembunuh itu akan melakukannya (Soesilo, 1995).

Sebenarnya yang menjadi masalah dari tindak pidana pembunuhan dipengaruhi oleh faktor lingkungan, emosi, sakit hati, dan juga kurangnya pendidikan yang dimiliki pelaku kejahatan juga 
Vera Eva Bonita Simbolon, Meri Simarmata \& Rahmayanti, Tinjauan Yuridis terhadap Tindak Pidana Pembunuhan Berencana Menggunakan Besi Padat di Medan Tinjauan Kasus Nomor 2305/Pid.B/2017/Pn.Mdn

menjadi faktor pendukung pelaku dalam melakukan kejahatan. Kurangnya pendidikan yang dimiliki pelaku membuat pelaku menjadi tidak berfikir terlebih dahulu akan akibat dari tindakan yang dilakukannya.

Walaupun aparat penegak hukum telah melakukan usaha pencegahan dan penanggulangannya, namun dalam kenyataanya masih saja terjadi dan bahkan beberapa tahun ini masih dapat dijumpai tindak kejahatan pembunuhan di Indonesia, pada umumnya yang terjadi di kota Medan yang cenderung meningkat. Pembunuhan yang terjadi tidak lepas dari kontrol sosial masyarakat, baik terhadap pelaku maupun terhadap korban pembunuhan sehinggamemberi peluang untuk berkembangnya tindak kejahatan atau kriminal.

Kitab Hukum Pidana (KUHP) terdapat beberapa bentuk atau jenis tindak pidana pembunuhan yang diatur dalam pasal 338 sampai dengan pasal 350 KUHP. Penerapan pasal-pasal tersebut mempunyai batasan ancaman sendiri misalnya untuk tindak pidana pembunuhan biasa diancam dengan hukuman maksimal 17 tahun penjara, sedangkan pembunuhan berencana diatur dalam pasal 340 KUHP yang diancam dengan hukuman penjara seumur hidup atau penjara selama-lamanya 20 tahun.
Peristiwa pembunuhan sering kali kita dengar, pelaku pembunuhantidak hanya dilakukan oleh orang lain tetapi juga bisa dilakukan oleh orang terdekat dalam hidup kita yang melakukan tindak pidana pembunuhan. Pembunuhan berencana bisa dilakukan dengan berbagai cara yaitu: membunuh dengan racun, atau membunuh dengan menggunakan besi padat dan lain sebagainya.

Maraknya pembunuhan pada zaman ini membuat kita ingin mengetahui faktorfaktor yang menjadi alasan seseorang melakukan pembunuhan berencana baik menggunakan alat atau tanpa menggunakan alat. Ini dapat kita lihat karena adanya banyak kasus-kasus pembunuhan berencana maupun pembunuhan biasa di Indonesia. Hal ini membuat masyarakat Indonesia ingin tahu tindakan apa yang dilakukan pemerintah dalam mengatasi pembunuhan baik itu pembunuhan berencana maupun pembunuhan biasa di Indonesia.

Faktor-faktor pembunuhan berencana itu sama baik menggunakan racun dan besi padat yang membedakan adalah dari barang buktinya, dimana barang bukti berupa racun sangat sulit untuk di identifikasi dari pada besi padat. Faktor-faktor eksternal dan internal dalam pembunuhan berencana maupun pembunuhan biasa yang membedakan 
dalam hal ini yaitu barang bukti yang berupa racun dan besi padat.

Penelitian ini penting karena penulis ingin mengetahui pertanggungjawaban pidana pelaku pembunuhan berencana dan untuk mengetahui dasar pertimbangan hakim dalam menjatuhkan sanksi pidana terhadap pelaku pembunuhan berencana tersebut.

Tindakan pembunuhan berencana dari tahun ke tahun meningkat. Setiap tahunnya tercatat begitu banyak kasus pembunuhan berencana di berbagai tempat di Indonesia. pelaku yang sering di temukan tak lain adalah orang terdekat dari korban tersebut. Utang piutang dan rasa sakit hati (dendam) merupakan pemicu terbesar dalam kasus-kasus tersebut. Berdasarkan survey yang dilakukan peneliti jumlah kasus pembunuhan di sumut terdapat 92 kasus pembunuhan sepanjang 2016 dan di seluruh Indonesia tercatat sejak tahun 2017 totalnya 783, terungkap 773. Tahun 2016 totalnya 1.197, terungkap 1.156. begitu banyak kasus yang tidak terungkap sepanjang tahun 2016-2017 (http://m.cnnindonesia.com diakses pada tanggal 27 mei 2019 pukul 10:42 WIB).

\section{METODE PENELITIAN}

Dalam penelitian ini mengenai tindak pidana pembunuhan berencana yang dilakukan dengan menggunakan besi padat. Tindak pidana ini dapat dilihat dari adanya kasus di kota Medan dengan Nomor 2305/Pid.B/2017/PN.Mdn.

Adapun pada penelitian ini penulis menggunakan metode penelitian pendekatan metode hukum yurudis normatif. Penelitian yuridis nomatif merupakan metode penelitian hukum yang melihat tentang isi dan penerapan peraturan peraturan perundangundangan yang dilengkapi dengan studi kasus dengan sifat penelitian deskriptif analisis.

Penelitian ini melakukan penelitian kepustakaan. Penelitian kepustakaan ditujukan untuk memperoleh data sekunder. Penelitian ini menggunakan metode yuridis normative yang bersifat kualitatif. Data yang didapatkan dari hasil penelitian pustaka (bahan hukum primer dan bahan hukum sekunder) maupun penelitian lapangan yang dianalisi. Data sekunder terdiri dari bahan hukum primer dan bahan hukum sekunder. Bahan hukum primer yaitu berbagai ketentuan dan peraturan perundang-undangan maupun undang-undang yang telah berlaku di Indonesia. Yang digunakan dalam penelitian ini merupakan Kitab Undang- 
Vera Eva Bonita Simbolon, Meri Simarmata \& Rahmayanti, Tinjauan Yuridis terhadap Tindak Pidana Pembunuhan Berencana Menggunakan Besi Padat di Medan Tinjauan Kasus Nomor 2305/Pid.B/2017/Pn.Mdn

Undang Hukum Pidana dan putusan Faktor-Faktor Pernyebab

Pengadilan Negeri Nomor

Ada 2 (dua) faktor-faktor penyebab

2305/PID.B/2017/Mdn. Bahan hukum

sekunder ini adalah bahan yang berkaitan

dengan bahan hukum primer dan

merupakan bahan pendukung dari bahan

hukum primer. Dalam penelitian ini

penulis mengambil bahan hukum

sekunder dari studi keperpustakaan,

mengumpulkan data dari perpustakaan,

literatur yang terdiri dari buku-buku yang terkait dari internet.

Penelitian ini mempertimbangkan putusan hakim yang memberatkan terdakwa dalam perkara nomor 2305/Pid.B/2017/PN Mdn dimana terdakwa telah mengakibatkan korban 6 orang meninggal dunia dan satu orang luka berat, yang menjadi korban dari perbuatan terdakwa tidak hanya dilakukan terhadap orang dewasa tetapi juga diantaranya terdapat korban terhadap anak, dan perbuatan terdakwa menjadi penyebab korban kehilangan seluruh sanak keluarga dan menimbulkan trauma sepanjang hidupnya. Dalam putusan tersebut Hakim memutuskan dan menjatuhkan pidana mati terhadap terdawakwa berdasarkan barang bukti sah dan saksi-saksi yang telah memberikan kesaksiannya dalam perkara ini.

\section{HASIL DAN PEMBAHASAN}

a. Faktor Internal

Merupakan sebab-sebab dan dalam diri sipentindak yang dapat dicari dan dianalisa dari kondisi sipetindak itu sendiri, yaitu meliputi:

1. Faktor Agama

Penyebab terjadinya suatu kejahatan ditentukan pada persoalan keharmonisan, agama atau hubungan antara manusia dengan Tuhan, menurut teori ini semakin jauh hubungan seseorang dengan Tuhannya melalui perantara agama yang dianutnya maka semakin dekat pula maksud seseorang untuk melakukan kejahatan (http://repository.usu.ac.id/bitstream/handle /123456789/Chapter diakses pada tanggal 5 November 2018 Pukul 11.00 Wib).

Salah satu penyebab terjadinya tindak pidana pembunuhan berencana menggunakan besi padat dikota Medan karena kurangnya pemahaman pelaku terhadap agama. Mereka mengaku beragama tetapi jarang melaksanakan ibadah sesuai dengan ajaran agama mereka, sehingga kurangnya pemahaman mereka terhadap agama maka mengakibatkan dia tidak mampu membedakan mana yang baik dan mana yang buruk, jadi kurangnya pemahaman seseorang terhadap agama akan mengakibatkan kontrol 
sosialnya tidak kuat sehingga mudah melakukan kejahatan.

\section{Faktor Keluarga}

Lingkungan keluarga dan masyarakat dapat memberikan dampak kejahatan. Keluarga merupakan organisasi terkecil namun mempunyai peranan yang sangat penting dalam kehidupan. Karena dari keluarga, kehidupan seseorang akan dapat terlihat penuh kebahagiaan, kasih sayang, saling pengertian diantara sesama anggota keluarga. Sehingga dalam hal ini seseorang akan cenderung berkembang dengan baik dalam berperilaku maupun dalam hidup ditengah-tengah masyarakat.

Dan sebaliknya bila dalam satu keluarga tidak terdapat kehamonisan, maka seseorang itu akan tumbuh dengan gaya hidup yang keras karena dari kecil seseorang itu tidak pernah mendapatkan kasih sayang dari kedua orang tuanya.Seseorang dalam masa pertumbuhannya ataupun dalam masa perkembangan hidupnya akan selalu terbawa sifat-sifat jahatnya, yang dianngap sebagai suatu kebiasaan dalam hidupnya sehingga mendorong seseorang itu menjadi pemarah, emosi dan pendendam ataupun dapat mengarah pada penyimpangan kejahatanan pembunuhan berencana

b. Faktor Eksternal

1. Faktor Ekonomi
Menurut Aristoteles menyatakan bahwa: Kemiskinan menimbulkan pemberontakan dan kejahatan. Dan kejahatan yang besar itu tidak diperbuat orang untuk mendapatkan kebutuhan-kebutuhan hidup yang vital, akan tetapi lebih banyak didorong oleh keserakahan manusia mengejar kemewahan dan kesenangan yang berlebihlebihan (Kartono, 2005).

Ekonomi merupakan suatu penunjang kehidupan setiap manusia, ekonomi atau keuangan dapat merupakan faktor yang dapat mempengaruhi terjadinya suatu pembunuhan. Misalnya pembunuhan dengan menggunakan besi padat. Dalam hal yang dimaksud tersebut ialah apabila seseorang mengalami himpitan atau kesusahan dalam bidang perekonomian, hal tersebut dapat mengganggu akal pikirannya dan dapat mengakibatkan orang tersebut akan mengalami stres berat, sehingga dapat membuat orang tersebut dapat melakukan sesuatu hal yang tak bisa dikontrol oleh dirinya sendiri.

b. Faktor Lingkungan

Dalam hal ini lingkungan sangat menentukan karakter seseorang untuk berkembang dengan baik dalam kehidupan bermasyarakatMenurut Soedjono D dan B simanjuntak, proses dimana orang bertindak adalah sebagai berikut (Meiliala \& Soemardjono, 1985): 
Vera Eva Bonita Simbolon, Meri Simarmata \& Rahmayanti, Tinjauan Yuridis terhadap Tindak Pidana Pembunuhan Berencana Menggunakan Besi Padat di Medan Tinjauan Kasus Nomor 2305/Pid.B/2017/Pn.Mdn

1) Tingkah laku itu dipelajari secara negatif dikatakan bahwa tingkah laku kriminal itu tidak diwarisi sehingga atas dasar itu tidak ada seseorang itu menjadi jahat secara mekanis.

2) Tingkah laku kriminal dipelajari dalam hubungan komunikasi dan dapat dilakukan dengan lisan ataupun dengan gerakan-gerakan badan yang mengandung suatu sikap tertentu.

c. Faktor Pendidikan

Baik buruknya jiwa seseorang tergantung dari salah satu faktor yaitufaktor pendidikan yang diberikan kepadanya. Baik pendidikan disekolah maupun pendidikan dirumah sendiri maupun diluar sekolah. Keburukan dan ketidak teraturan maupun kekacauan pendidikan pengajaran yang dialami seseorang dalam perkembangannya dapat merangsang dan mempengaruhi tingkah laku seseorang itu terhadap perbuatan-perbuatan jahat. Rendahnya tingkat pendidikan formal dalam diri seseorang dapat menimbulkan dampak terhadap masyarakat yang bersangkutan mudah terpengaruh melakukan suatu kejahatan tanpa memikirkan akibat dari perbuatannya

(http://www.areabaca.com/2013/11/penger tian-sekolah.htmldiakses pada tanggal 07 November 2018 Pukul 15.00 Wib).

d. Faktor Pengaruh Obat-Obatan Terlarang
Pengaruh obat-obatan terlarang, mempunyai akibat yang sangat buruk terhadap kesehatan tubuh dan jiwa (akal pikiran). Pengaruh dari obat-obatan terlarang itu dapat menyebabkan seseorang itu menjadi ketagihan dan kehilangan penguasaan diri dan dapat melakukan hal-hal yang buruk akibat dari obat-batan tersebut, dan akan mendorong mereka untuk mencari kepuasaan diri untuk menyalurkan keinginannya dengan melakukan kejahatanseperti pembunuhan berencana menggunakan besi padat.

\section{e. Faktor Media Sosial}

Seperti yang sudah kita ketahui bahwa pengaruh internet memang sudah semakin besar pengaruhnya di zaman teknologi ini. Tidak sedikit yang menjadi "ketergantungan" dengan internet. Dari semua kalangan, baik tua maupun muda. Internet sudah menjadi kebutuhan banyak orang, dimana internet bisa menjadi sumber pengetahuan atau pemberi informasi yang mendunia maupun sumber pengahasilan. Banyak orang yang memanfaatkannya sebagai sesuatu yang positif, namun ada juga yang menggunakannya sebagai sesuatu yang negatif.

Dalam analisis putusan terdapat hampir dari keseluruhan faktor yang terdapat di atas merupakan faktor yang mendasari terjadinya pembunuhan berencana tersebut untuk lebih spesifiknya faktor yang lebih mempengaruhi menurut penulis ialah faktor 
ekonomi karena dari hasil analisis penulis menemukan adanya permasalahan ekonomi yang mendasari terjadinya tindak pidana tersebut.

\section{Pertanggungjawaban Tindak Pidana}

Mengenai pembunuhan berencana diatur dalam Pasal 340 KUHP, yang bunyinya antara lain sebagai berikut:"Barang siapa dengan sengaja dan dengan direncanakan lebih dahulu menghilangkan jiwa orang lain, dihukum, karena pembunuhan direncanakan (moord), dengan hukuman mati atau penjara seumur hidup atau penjara sementara selamalama dua puluh tahun" (Soesilo, 1995).

Unsur-unsur tindak pidana dibagi menjadi dua yaitu (Anwar, 1994): Unsur Subjektif yaitu dengan sengaja dan atau direncanakan terlebih dahulu, "Hilangnya nyawa seseorang harus dikehendaki, harus menjadi tujuan. Suatu perbuatan dilakukan dengan maksud atau tujuan atau niat untuk menghilangkan jiwa seseorang, timbulnya akibat hilangnya seseorang tanpa dengan sengaja atau maksud, tidak dapat dinyatakan sebagai pembunuhan, jadi dengan sengaja berarti mempunyai maksud atau niat atau tujuan untuk menghilangkan jiwa seseorang".

Unsur Objektif: menghilangkan nyawa orang lain. Semua unsur tindak pidana pembunuhan diatas telah dibicarakan pada waktu membicarakan tindak pidana pembunuhan dalam bentuk pokok, kecuali unsur dengan unsur dengan direncanakan terlebih dahulu. Pada pasal 340 dirumuskan dengan cara mengulang kembali seluruh unsur dalam pasal 338, kemudian ditambah dengan satu unsur lagi yakni “dengan rencana terlebih dahulu". Oleh karena dalam pasal 340 mengulang lagi mengulang lagi seluruh unsur pasal 338, maka pembunuhan berncana dapat dianggap sebagai pembunuhan yang berdiri sendiri. Apalagi pembunuhan berencana itu dimaksudkan oleh pembentuk undangundang sebagai pembunuhan bentuk khusus yang memberatkan.

Menurut M. Sudrajat Bassar unsurunsur tindak pidana pembunuhan berencana dibagi menjadi 3 yaitu (1986): Adanya kesengajaan (Dolus premiditanu), yaitu kesengajaan yang harus disertai dengan suatu perencanaan terlebih dahulu. Yang bersalah dalam keadaan tentang memikirkan untuk melakukan pembunuhan itu dan kemudian melakukan maksudnya dan tidak menjadi soal berapa lama waktunya. Diantara saat timbulnya pikiran untuk membunuh dan saat melakukan pembunuhan itu, ada waktu ketenangan pikiran. Umpannya yang bersalah memikirkan membunuh dalam keadaan marah atau terharu ingatannya toh melakukan juga pembunuhan itu. 
Vera Eva Bonita Simbolon, Meri Simarmata \& Rahmayanti, Tinjauan Yuridis terhadap Tindak Pidana Pembunuhan Berencana Menggunakan Besi Padat di Medan Tinjauan Kasus Nomor 2305/Pid.B/2017/Pn.Mdn

Pertanggungjawaban Pelaku Tindak memungkinkan peraturan hukum positif

\section{Pidana Pembunuhan Berencana}

Tujuan hukum pidana ialah untuk memenuhi rasa keadilan, mendidik atau memperbaiki orang-orang yang sudah menandakan suka melakukankejahatan, agar menjadi orang yang baik tabiatnya sehingga dapat bermanfaat bagi masyarakat dan juga dengan adanya hukum pidana yang bersifat represif diharapkan pelaku tindak pidana tidak mengulang perbuatannya dan apabila kembali ke masyarakat dapat diterima seperti dahulu sebelum ia di penjara. Aturan hukum mengenai tindak pidana mempunyai struktur yang berbeda dengan aturan hukum mengenai bagaimana reaksi terhadap mereka yang melanggarnya. Artinya, penegakan terhadap kewajiban-kewajiban tersebut memerlukan suatu program aplikasi yang dinamakan system pertanggungjawaban pidana (Huda, 2006). Mahrusali, menjelaskan pertanggungjawaban pidana adalah pertanggungjawaban orang terhadap tindak pidana yang dilakukannya (Ali, 2012).

Pertimbangan Hakim Dalam Menjatuhkan Putusan Pidana

Istilah "kebijakan" diambil dari istilah "policy" (inggris) atau "politiek" (Belanda). Menurut Marc Ancel, pengertian kebijakan hukum pidana (penal policy) adalah suatu ilmu sekaligus seni yang pada akhirnya mempunyai tujuan praktis untuk dirumuskan secara lebih baik dan untuk memberi pedoman tidak hanyak kepada pembuat undang-undang dan juga kepada penyelenggara atau pelaksana putusan pengadilan (Arief, 2011).

Barda Nawawi Arief menyatakan bahwa pada hakikatnya masalah kebijakan hukum pidana bukanlah semata-mata pekerjaan teknik perundang-undangan yang dapat dilakukan secara yuridis normative dan sistematik dogmatik. Disamping pendekatan yuridis faktual juga dapat berupa pendekatan komprehensif dari berbagai disiplim ilmu sosial lainnya dan pendekatan integral dengan kebijakan social dan pembangunan nasional pada umumnya (Arief, 2011).

Upaya represif adalah suatu upaya penanggulangan kejahatan secara konsepsioanal yang ditempuh setelah terjadinya kejahatan. Penanggulangan dengan represif untuk menindak para pelaku sesuai dengan perbuatannya serta memperbaikinyakembali agar mereka sadar bahwa perbuatan yang dilakukannya adalah perbuatan melanggar hukum dan merugikan masyarakat, sehingga tidak mengulanginyadan orang lain juga tidak akan melakukannya mengingat sanksi yang ditanggungnya sangat berat (http://handarsubhandi.blogspot.co.id/2015/ 08/Upaya-penanggulangan-kejahatan.html 
diakes pada tanggal 07 November 2018 Pukul 16.00 Wib).

Kebijakan Non Penal, secara sederhana dapat dibedakan, bahwa upaya penanggulangan kejahatan lewat jalur penal lebih menitikberatkan pada sifat "represif" (penindasaan/pemberantasan/penumpasan) sesudah kejahatan terjadi, sedangkan jalur non-penal lebih menitikberatkan pada tindakan preventif (pencegahan/pengendalian) sebelum kejahatan terjadi, namun dalam tindakan represif juga didalamnya terkandung tindakan preventif dalam arti luas (Soedarto, 1986).

Upaya penanggulangan kejahatan nonpenal dapat berupa (http://hasniaabni,blogspot.co.id/2013/04/u paya-penal-dan-non-penal-dalam.html diakses pada tanggal 07 November 2018 Pukul 17.00 Wib) Pencegahan tanpa pidana (Prevention without punishment) dan Mempengaruhi pandangan masyarakat mengenai kejahatan dan pemidanaan lewat media massa (Influencing views of society on crime and punishment mass media). Upaya penanggulangan kejahatan lewat jalur nonpenal lebih bersifat akan pencegahan untuk terjadinya kejahatan, maka sasaran utamanya adalah menangani faktor-faktor kondusif penyebab terjadinya kejahatan. Faktor-faktor kondusif itu antara lain berpusat pada masalah-masalah atau kondisi-kondisi sosial yang secara langsung atau tidak langsung dapat menimbulkan atau menumbuhsuburkan kejahatan (http://stisiprappang.blogspot.co.id/2011/07 /kejahatan-dalam-masyarakat-danupaya.html diakses pada tanggal 07 November 2018 Pukul 17.00 Wib).

\section{Analisa Kasus Putusan Nomor 2350/Pid.B/2017/PN.Mdn}

Kronologi Kasus: Terdakwa ANDI LALA Als.ANDI MATALATA pada hari minggu tanggal 12 Juli 2017 sekitar pukul 20.30 wib, atau setidak-tidaknya pada waktu lain dalam bulan Juli 2017 bertempat dirumah terdakwa di Jln. Pembangunan II Desa Skip Kec.Lubuk Pakam Kab.Deli Serdang atau setidak-tidaknya disalah satu tempat lain yang masih termasuk daerah Hukum Pengadilan Negeri Deli Serdang akan tetapi berdasarkan pasal 84 ayat (2) KUHAP, Pengadilan Negeri Medan berwenang mengadili perkara terdakwa tersebut karena terdakwa ditahan di LP Tanjung Gusta Medan, dan tempat kediaman sebagian besar saksi yang dipanggil lebih dekat pada tempat kedudukan pengadilan Negeri yang didalam daerahnya tindak pidana itu dilakukan pada hari Sabtu 08 April 2017 sekitar jam 23.30 Wib atau setidak-tidaknya pada waktu lain dalam bulan April 2017 bertempat di Jalan Kayu Putih Kelurahan Mabar Kecamatan Labuhan Deli Kota Medan 
Vera Eva Bonita Simbolon, Meri Simarmata \& Rahmayanti, Tinjauan Yuridis terhadap Tindak Pidana Pembunuhan Berencana Menggunakan Besi Padat di Medan Tinjauan Kasus Nomor 2305/Pid.B/2017/Pn.Mdn

atau setidak-tidaknya disalah satu tempat lain yang masih termasuk daerah Hukum Pengadilan Negeri Medan, telah melakukan beberapa perbuatan yang harus dipandang sebagai perbuatan yang berdiri sendirisendiri, mereka yang melakukan dan yang turut serta melakukan perbuatan dengan sengaja dan dengan rencana terlebih dahulu merampas nyawa orang lain.

Adapun bentuk dakwaan penuntut umum terhadap perbuatan yang dilakukan oleh terdakwa yang menimbulkan akibat hilangnya nyawa korban adalah Bahwa ia terdakwa ANDI LALA Alias ANDI MATALATA, pada hari sabtu tanggal 08 April 2017 sekitar jam 23.30 Wib atau setidak-tidaknya pada waktu lain dalam bulan April 2017 bertempat di Jalan Kayu Putih Kelurahan Mabar, atau setidak-tidaknya disuatu tempat lain yang masih termasuk dalam daerah hukum Pengadilan Negri Medan yang berwenang untuk memeriksa dan mengadilinya, “beberapa perbuatan yang ahrus dipandang sebagai perbuatan yang berdiri sendiri-sendiri mengambil barang yang sama sekali atau sebagian kepunyaan orang lain, dengan maksud untuk memiliki barang itu dengan melawan hukum, yang didahului, disertai atau diikuti dengan kekerasaan atau ancaman kekerasaan atau ancaman kekerasan pada orang, dengan maksud untuk menyediakan atau memudahkan pencurian itu atau jika tertangkap tangan, supaya ada kesempatan bagi dirinya atau bgai yang turut serta yang melakukan kejahatan itu untuk melarikan diri atau supaya barang yang dicurinya tetap tinggal ditangannyajika perbuatan tersebut mengakibatkan luka berat atau mati dan dilakukan oleh dua orsng atau lebih dengan bersekutu diwaktu malam dalam sebuah rumah".

Tuntutan jaksa penuntut umum pada pokoknya Menyatakan terdakwa ANDI LALA Alias ANDI MATALATA terbukti secara sah dan menyakinkan bersalah melakukan tindak pidana "telah melakukan beberapa perbuatan yang harus dipandang sebagai perbuatan yang berdiri sendiri-sendiri, mereka yang melakukan dan yang turut serta melakukan perbuatan dengan sengaja dan dengan rencana terlebih dahulu merampas nyawa orang lain" sebagaimana diatur dan diancam pidana dalam pasal 340 KUHP Jo. Pasal 55 ayat (1) ke-1 KUHP jo pasal 65 ayat (1) KUHP dalam dakwaan kesatu primair. Menjatuhkan pidana terhadap terdakwa ANDI LALA Alias ANDI MATALATA dengan pidana MATI.

Menimbang, bahwaberdasarkan keterangan saksi, keterangan terdakwa dan juga berdasarkan barang bukti yang diajukan dipersidangan telah di peroleh fakta-fakta hukum, sebagai berikut "Bahwa saksi Syahria, merangkan bahwa pada hari minggu tanggal 09 April 2017 sekitar jam 07.30 Wib, saksi saat menjemur pakaian melihat rumah korban Riyanto dalam keadaan tertutup dan lampu 
depan masih menyala, saksi mengira korba Riyanto mungin masih tidur, dan ketika saksi hendak berbelanja bersama saksi serimpi, saksi melihat saksi Serimpi berteriak-teriak di depan rumah korban Riyanto, lalu saksi mendatangi rumah korban Riyanto,ketika berada di depan rumah korban Riyanto saksi Serimpi memberitahukan, korban tergeletak dan kepalanya berdarah, selanjutnya saksi menemui orangtua korban bernama Wagiman dan memberitahukan keadaan korban di tempat kejadian yang dimana saat wagiman masuk untuk melihat korban wagiman mendapati istri, anak, dan mertua Riyanto turut menjadi korban dan meninggal dunia".

Dalam mengadili menyatakan terdakwa ANDI MATALATA terbukti sah dan menyakinkan bersalah melakukan tindak pidana Turut serta melakukan beberapa perbuatan pembunuhan yang direncanakan terlebih dahulu sebagaimana diatur dalam dakwaan Alternatif kesatu primar, menjatuhkan pidana terhadap terdakwa dengan pidana mati, menetapkan barang bukti, membebankan biaya perkara kepada Negara dan Analisis yang dihasilkan dalam putusan No. 2305/Pid.B/2017/PN.Mdn yaitu,, proses pengambilan keputusan yang dilakukan oleh Majelis Hakim menurut Penulis sudah sesuai dengan aturan hukum yang berlaku seperti yang dipaparkan oleh penulis sebelumnya, yaitu berdasarkan alat bukti yang sah, dimana dalam kasus ini, alat bukti yang digunakan Hakim adalah Keterangan saksi, alat bukti surat dalam hal ini visum et repertum keterangan terdakwa, serta diperkuat adanya barang bukti yang dipakai terdakwa dalam melakukan pembunuhan. Kesesuaian antara masing-masing alat bukti serta barang bukti, maka akan diperoleh fakta hukum yang menjadi dasar bagi hakim untuk memperoleh keyakinan. Lalu kemudian mempertimbangkan tentang pertanggungjawaban pidana, dalam hal ini Majelis Hakim berdasarkan fakta-fakta yang timbul dipersidangan menilai bahwa terdakwa dapat dipertanggungjawabkan atas perbuatan yang dilakukan dengan pertimbangan bahwa saat melakukan perbuatannya, terdakwa sadar akan akibat yang ditimbulkannya. Terdakwa dalam melakukan perbuatannya berada pada kondisi yang sehat dan cukup untuk mempertimbangkan perbuatannya. Dalam menjatuhkan putusan hukuman mati terhadap terdakwa, penulis sependapat dengan vonis Majelis Hakim yang memberikan pidana mati. Menurut penulis hukuman itu sudah cukup pantas untuk terdakwa dilihat dari banyaknya korban yang meninggal dunia dimana terdakwa menghabisi korban dengan begitu sadis rasanya itu cukup pantas. Dan juga kasus ini bisa jadi pembelajaran bagi banyak orang 
Vera Eva Bonita Simbolon, Meri Simarmata \& Rahmayanti, Tinjauan Yuridis terhadap Tindak Pidana Pembunuhan Berencana Menggunakan Besi Padat di Medan Tinjauan Kasus Nomor 2305/Pid.B/2017/Pn.Mdn

bahwa masalah pasti ada jalan keluarnya penjara paling lama seumur hidup atau untuk menyelesaikannya bukan dengan pidana mati.

membunuh dan menambah masalah pada diri

Kebijakan hukum pidana terhadap sendiri.

\section{SIMPULAN}

Penyebab terjadi tindak kejahatan pembunuhan terhadap jiwa orang lain diprakarsai 2 faktor yakni internal dan eksternal, yang mana faktor internal diantarnya kurangnya pemahaman sesorang terhadap agama dan berakibat mudanya seseorang melakukan kejahatan, dan kurangnya keharmonisan dalam keluarga juga berpengaruh terhadap sikap seseorang yang dapat memicu seseorang itu dapat berbuat kejahatan, sedangkan faktor eksternal diantaranya karena pengaruh lingkungan yang memberikan pelakukemudahan untuk menjalankan aksinya, pendidikan pelaku yang begitu rendah juga merupakan faktor yang mempengaruh karena tidak sadar hukum sehingga mudah dalam melakukan pembunuhan, faktor ekonomi juga mempengaruhi keadaan jiwa, tingkah laku terutama intelegensinya sehingga pelaku dapat melakukan kejahatan.

Pengaturan hukum tentang pembunuhan berencana ini diatur dalam pasal 340 KUHP tentang pembunuhan berencana dimana pelaku akan dikenakan

\section{DAFTAR PUSTAKA}

Meiliala, A.Q.S. \& Sumaryono, E. (1985). Kejahatan Anak Suatu Tinjauan dari Psikologi dan Hukum. Yoygyakarta: Liberty.

Anwar, H.A.K.M, (1994). Hukum Pidana Bagian Khusus (Kuhp Buku II) Jilid I. Bandung: Citra Aditya Bakti.

Ali, M. (2012). “Dasar-dasar Hukum Pidana”. Jakarta: Sinar Grafika.

Arief, B.N. (2011). Bunga Rampai kebijakan Hukum Pidana. Jakarta: Prenada Media Group.

Huda, C. (2006). Dari tiada Pidana tanpa kesalahan menuju kepada tiada Pertanggungjawaban pidana tanpa kesalahan. Jakarta: Perda Kencana.

Samosir, D. (1992). Fungsi Pidana penjara dalam Sistem Pemidanaan di Indonesia. Bandung: Bina Cipta.

Hamzah, A. (2001). Bunga Rampai Hukum Pidana dan Acara Pidana. Jakarta: Ghalia Indonesia.

Asshiddiqie, J. (2006), Konstitusi dan Konstitusionalisme, Sekretariat Jenderal dan kepaniteraan Mahkamah Konstitusi RI, Jakarta.

Kartono, K. (2005) Patologi Sosial Jilid I. Jakarta: PT. Raja Grapindo Presada.

Librayanto, R. (2012). Ilmu Negara (Suatu Pengantar). Makasar: Refleksi.

Muladi. (2002). Lembaga Pidana Bersyarat. Bandung: Alumni.

Muladi \& Arief, B.N. (2011). Teori-teori dan kebijakan pidana. Bandung: Alumni.

Prodjodikoro, W. (2012). Asas-asas Hukum Pidana di Indonesia. Jakarta: Refika Aditama. 
Soesilo, R. (1995). Kitab undang-undang Hukum Pidana serta komentar-komentarnya lengkap pasal demi pasal. Bogor: Politea.

Sudarto. (1986). Kapita Selekta Hukum Pidana, Alumni, Bandung.

Soekanto, S. (2007). Sosiologi suatu pengantar. Jakarta: PT. Raja Grafindo.

Soerjono, S. (1984). Pengantar Penelitian Hukum Normatif. Jakarta: Rajawali Press.

http://repository.usu.ac.id/bitstream/handle/12345678 9/Chapter diakses pada tanggal 5 November 2018 Pukul 11.00 Wib

http://www.areabaca.com/2013/11/pengertiansekolah.htmldiakses pada tanggal 07 November 2018 Pukul 15.00 Wib 